

JPE (2017) Vol.20 (2)

Payal, H.

Original Scientific Paper

\title{
ANALYSIS OF TOOL MATERIAL ON METAL REMOVAL RATE IN ELECTRICAL DISCHARGE MACHINING
}

Received: 04 November 2017 / Accepted: 12 December 2017

\begin{abstract}
H11 tool steel is an exceptional class of alloy steel, also known as chromium tool steel. It found applications in forging and extrusion dies, helicopter rotor blades etc. Electrical discharge machining (EDM) is one of the alternative processes to shape this material. This study exhibits the effect of discharge current $\left(I_{d}\right)$ and gap voltage $(\mathrm{Vg})$ on metal removal rate (MRR) during EDM of $\mathrm{H1} 1$ tool steel by taking three different tool electrode materials. Experiments have been performed by varying $I_{d}$ in four steps $(4 \mathrm{~A}, 8 \mathrm{~A}, 12 \mathrm{~A}, 16 \mathrm{~A})$ and $\mathrm{V}_{\mathrm{g}}$ in $(25 \mathrm{~V}, 30 \mathrm{~V}$, $35 \mathrm{~V}, 40 \mathrm{~V}$ ) while keeping the values of other variable fixed. On the basis of experimental findings, it is concluded that tool properties of the electrode play a crucial role in machining characteristics of EDM process. The results show that graphite electrode offers the higher MRR followed by aluminium and copper electrode in EDM of H11 tool steel.
\end{abstract}

Key words: EDM, metal removal rate (MRR), H11 (hot die steel), discharge current, gap voltage

Analiza uticaja alatnog materijala na količinu skinutog materijala kod mašina za elektro erozivonu obradu. H11 alatni čelik je izuzetna klasa legiranog čelika, poznatog i kao hromski alatni čelik. Ovaj materijal je pronašao primenu kod kovanja i ekstruzije, rotacionih lopatica helikoptera itd. Elektro eroziona obrada (EDM) je jedan od alternativnih procesa za oblikovanje ovog materijala. Ova studija pokazuje uticaj struje pražnjenja (Id) i napona pažnjenja (Vg) na brzinu skidanja metala (MRR) tokom EDM obrade H11 alatnog čelika sa tri različita materijala alata elektrode. Eksperimenti su izvršeni promenom Id-a u četiri koraka (4A, 8A, $12 \mathrm{~A}, 16 \mathrm{~A})$ i Vg u $(25 \mathrm{~V}, 30 \mathrm{~V}, 35$ $V, 40 \mathrm{~V}$ ) dok se vrednosti druge varijabli drže fiksne. Na osnovu eksperimentalnih nalaza, zaključeno je da svojstva alata elektrode igraju presudnu ulogu u mašinskim karakteristikama EDM procesa. Rezultati pokazuju da grafitna elektroda nudi veću kolićinu skinutog materijala MRR u odnosu na aluminijumsku i bakarnu elektrodu tokom obrade H11 alatnog čelika pomoću EDM.

Ključne reči: EDM, brzina skidanja metala (MRR), H11 (čelik za kalupe), struja pražnjenja, napon pražnjenja

\section{INTRODUCTION}

H11, a special hot worked chromium tool steel with good hardness and toughness found suitable applications in the production of extrusion, forging and die casting dies etc. Due to its special class it found its usage in aerospace industries, helicopter rotor blades and shafts [1]. Due to its typical properties it found difficulty in the machining process by conventional methods. Non-conventional methods is found to be one of the options for machining H11 tool steel. EDM is an unconventional, non-contact machining process in which material removal takes place by the help of electrical discharges occurring between tool electrode and the work piece separated by dielectric medium. The amount of heat generated by the electrical sparks is around $8000-10000^{\circ} \mathrm{C}$ which is sufficient to melt the material as well as electrode also. EDM is known for its thermal behavior which can machine any electrically conductive material regardless of its strength and hardness [2]. EDM is a stochastic process whose performance depends on the input parameters chosen. Thus, certain input parameters when varied directly effects the performance measures such as MRR, tool wear rate, surface roughness of the machined work piece. A lot of work has been reported in the literature with regard to high MRR in the field of EDM. Singh et al. [3] studied the influence of electrode type and material on the EDM process by taking EN-31 tool steel as a work piece and copper, copper-tungsten, aluminum, and brass as an electrode material. They reported that copper electrode showed better results related to MRR, diameter overcut, TWR and SR followed by the aluminium electrode. Muthuramalingam and Mohan [4] investigated the importance of tool electrode materials (copper, brass, tungsten carbide) on the machining performance of AISI 2020 stainless steel in EDM process. They reported that copper electrode produces higher MRR and tungsten carbide electrode showed better surface finish. Dewangan et al. [5] examined the effects of EDM parameters as well as tool electrode materials (copper, brass and graphite) onAISIP20 tool steel .They have reported that graphite tool showed better results in regards to white layer thickness, surface crack density and SR followed by brass, copper. Lee and $\mathrm{Li}$ [6] performed an experimental investigation on EDM for Tungsten carbide material using copper, copper tungsten and graphite as tool electrode material. They have taken MRR, SR, TWR as the performance measures. It was observed from the results that graphite electrode offers higher MRR whereas copper electrode showed higher TWR but better surface finish. They also reported that with negative tool polarity maximum MRR, minimum TWR and SR could be achieved. Payal 
et al. [7-8] studied the machining characteristics of H11 and H13 material by taking three electrode material i.e. aluminum, copper and graphite. They reported that copper electrode achieved the best surface finish among other electrodes.

In the present work, the objective is to investigate the machining characteristics of H11 tool steel material using three different electrode materials viz. copper(Cu), graphite (Gr), aluminum (Al). The discharge current and gap voltage has been varied in four steps to study the MRR.

\section{EXPERIMENTATION}

The experiments were conducted on EDM machine (S645CNC) of OSCARMAX a Taiwan company installed at Central Institute of Hand Tools, Jalandhar, India as shown in figure 1.The commercial grade EDM oil was used as a dielectric fluid. The work piece material was AISI H11 tool steel with rectangular in shape of $125 \mathrm{~mm} \times 100 \mathrm{~mm} \times 24 \mathrm{~mm}$ size. Figure 2 shows the machining of H11 work piece Three different tool electrodes of cylindrically shaped namely Copper $(\mathrm{Cu})$, Graphite $(\mathrm{Gr})$ and aluminum as shown in figure 3 were used in the present study. Figure 4 depicts the machining by $\mathrm{Cu}$ electrode. Typical mechanical properties and chemical composition of $\mathrm{H} 11$ are depicted in table 1and table 2.

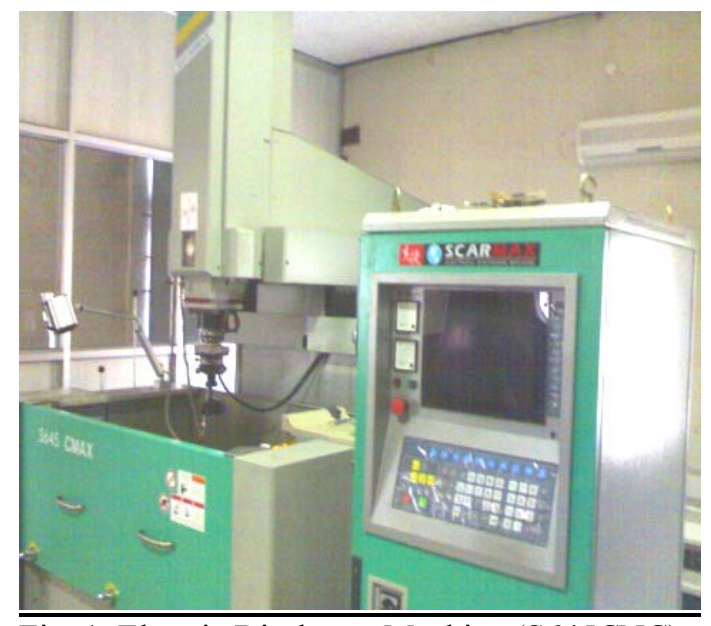

Fig. 1. Electric Discharge Machine (S645CNC)



Fig. 2. Hot die steel H11 during Machining

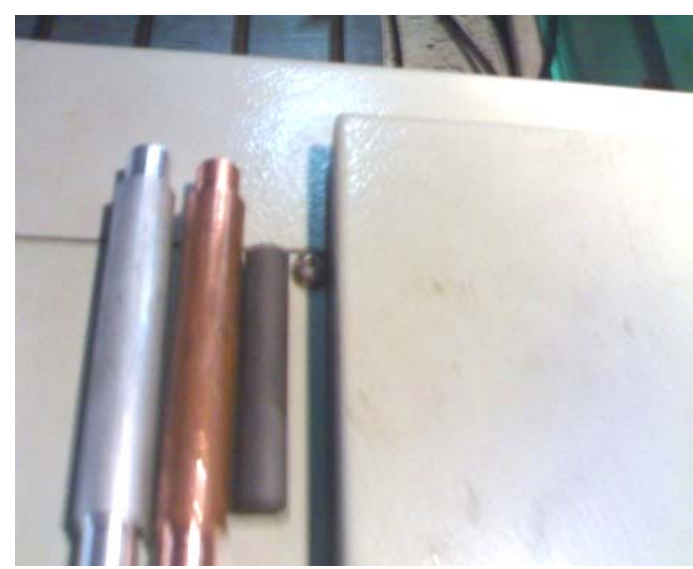

Fig. 3.Tool electrodes used

The input parameter discharge current and gap voltage has been varied in four steps. The MRR is taken as the performance measures. MRR is calculated by evaluating the weight loss of work piece using equation 1 respectively.

$$
M R R=\frac{W_{i}-W_{f}}{\rho t} m m^{3} / \min
$$

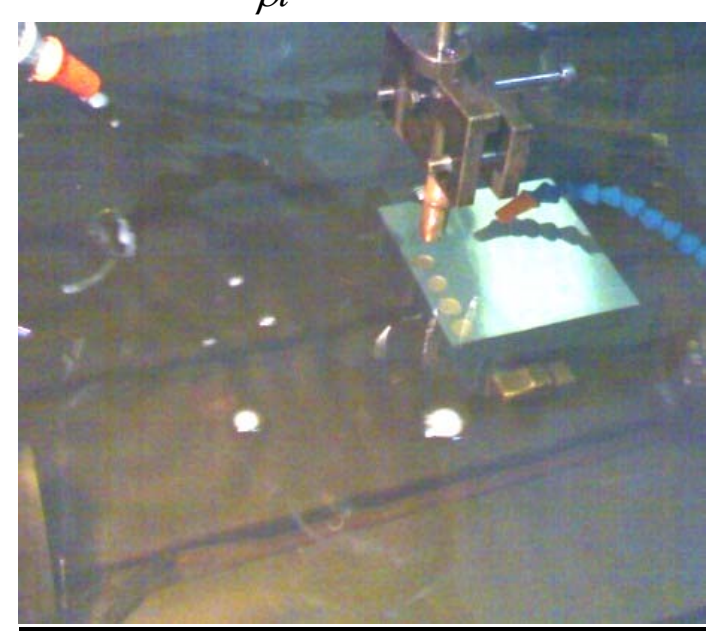

Fig. 4. Machining by $\mathrm{Cu}$ electrode

\begin{tabular}{|l|l|l|}
\hline Property & Unit & Value \\
\hline Density & $\mathrm{g} / \mathrm{cm}^{3}$ & 7.81 \\
\hline Melting Point & ${ }^{\circ} \mathrm{C}$ & 1427 \\
\hline Elastic modulus & $\mathrm{GPa}$ & 207 \\
\hline $\begin{array}{l}\text { Thermal } \\
\text { expansion }\end{array}$ & $\left(10-6 /{ }^{\circ} \mathrm{C}\right)$ & 11.9 \\
\hline $\begin{array}{l}\text { Thermal } \\
\text { conductivity }\end{array}$ & $(\mathrm{W} / \mathrm{m}-\mathrm{K})$ & 42.2 \\
\hline Hardness & HRC & 57 \\
\hline
\end{tabular}

Table 1. Mechanical properties of H11

\begin{tabular}{|l|l|}
\hline Elements & Wt. \% age \\
\hline $\mathrm{C}$ & 0.648 \\
\hline $\mathrm{Si}$ & 0.603 \\
\hline $\mathrm{Mn}$ & 0.262 \\
\hline $\mathrm{P}$ & 0.0078 \\
\hline $\mathrm{S}$ & 0.0145 \\
\hline $\mathrm{Cr}$ & 5.17 \\
\hline $\mathrm{Mo}$ & 1.23 \\
\hline $\mathrm{V}$ & 0.756 \\
\hline
\end{tabular}

Table 2. Chemical composition (wt \%) of H11 material 


\section{RESULTS AND DISCUSSION}

On the basis of experimental results, the effect of discharge current and gap voltage on MRR with different tool electrode materials has been shown in table 4 and 5 and .Diagrammatic representation is shown in Figure 5 and 6. Figure 5 indicates that MRR increases with increase in discharge current for all the three electrode material. This is due to the fact that MRR is directly proportional to discharge current and another reason is that at higher discharge current the intensity of the sparks will increase which causes larger overcuts and more material is removed from the surface.

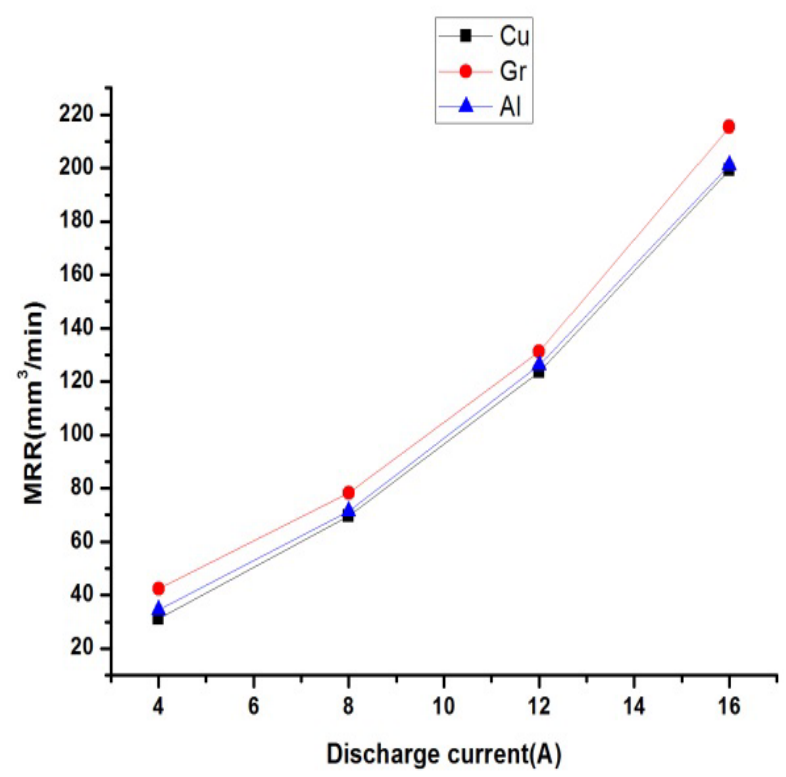

In the present work, the results depicts that graphite electrode exhibits higher MRR followed by aluminium and copper. This confirms that thermo physical properties of the electrode material play crucial role in MRR. The melting point of electrode material can also be linked up with the MRR of work piece. Figure 6 indicates the graph between gap voltage and MRR which indicates the increment in MRR with increase of gap voltage for all the three electrode materials. It was observed that an increase in gap voltage caused an increase in MRR for given constant parameters up to certain voltage. This is due to the fact that pulse energy increases with gap voltage.

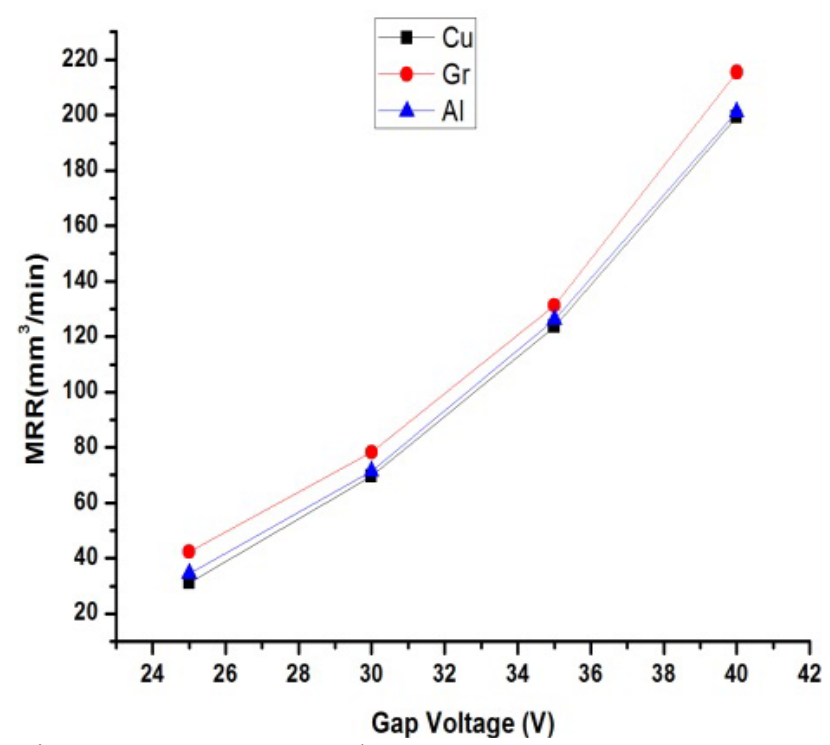

Fig. 6. MRR Vs Gap Voltage

Fig. 5. MRR Vs Discharge Current

\begin{tabular}{|c|c|c|c|}
\hline $\begin{array}{c}\text { Discharge } \\
\text { Current }(\mathrm{A})\end{array}$ & MRR by Cu $\left(\mathrm{mm}^{3} / \mathrm{min}\right)$ & MRR by $\mathrm{Gr}\left(\mathrm{mm}^{3} / \mathrm{min}\right)$ & MRR by Al $\left(\mathrm{mm}^{3} / \mathrm{min}\right)$ \\
\hline 4 & 31.29 & 42.39 & 34.39 \\
\hline 8 & 69.61 & 78.28 & 71.26 \\
\hline 12 & 123.51 & 131.21 & 126.11 \\
\hline 16 & 199.31 & 215.39 & 201.05 \\
\hline
\end{tabular}

Table 3. Effect of discharge current on MRR for H11 material

\begin{tabular}{|c|c|c|c|}
\hline $\begin{array}{c}\text { Gap Voltage } \\
(\mathrm{V})\end{array}$ & MRR by Cu $\left(\mathrm{mm}^{3} / \mathrm{min}\right)$ & MRR by Gr $\left(\mathrm{mm}^{3} / \mathrm{min}\right)$ & MRR by Al $\left(\mathrm{mm}^{3} / \mathrm{min}\right)$ \\
\hline 25 & 31.29 & 42.39 & 34.39 \\
\hline 30 & 69.61 & 78.28 & 71.26 \\
\hline 35 & 123.51 & 131.21 & 126.11 \\
\hline 40 & 199.31 & 215.39 & 201.05 \\
\hline
\end{tabular}

Table 4. Effect of gap voltage on MRR for H11 material

\section{CONCLUSION}

The experimental study has been conducted to investigate the effect of discharge current and gap voltage during EDM of AISI H11 tool steel material by taking three different tool electrode materials. The value of MRR increases with increase in discharge current and gap voltage value. In the instant case, it is concluded that graphite offers the higher MRR followed by aluminium and copper.

\section{REFERENCES}

[1] Yamanaka, M., Tamura, R., Inoue, K. and Narita, Y.: Bending fatigue strength of austempered ductile iron spur gears, Journal of Advanced Mechanical Design, Systems and Manufacturing, vol. 3(3), (2009), 203-211.

[2] Qamar,Z.S.: Effect of heat treatment on mechanical properties of $H 11$ tool steel,Journal of Achievements in Material and Manufacturing Engineering, 35/2, 115-120,2009 
[3] Mathew,N.,Kumar,D., Beri ,N., Kumar,A., Study Of Material Removal Rate Of Different Tool Materials During Edm Of H11 Steel At Reverse Polarity, International Journal of Advance Engineering Technology,Vol.5(2),p.p25-30,2014.

[4] Puertas,I.,Luis,J.C.,Villa,G.: Space roughness parameter study on the EDM of silicon carbide, Journal Material process technology 164-165, p.p.1590-1596, 2005.

[5] Muthuramalingam,.T., Mohan,.B.:Influence of Tool Electrode Properties on Machinability in Spark Erosion Machining, Materials and Manufacturing Processes, Vol.28, 939-943, 2013.

[6] Dewangan, S., Biswas, K.C.,Gangopadhyay, S.: Influence of Different Tool Electrode Materials on EDMed Surface Integrity of AISI P20 Tool Steel, Materials and Manufacturing Processes, Vol.29, 1387-1394, 2014.

[7] Lee.H.S.,Li.P.X.:Study of the effect of machining parameters on the machining characteristics in electrical discharge machining of tungsten carbide,Journal of MaterialProcessing

Technology,Vol.115,p.p.344-358.

[8] Payal, Himanshu, Garg, RK.,Sachdeva, A.: Investigation of surface integrity of Hot die steel after EDM, International conference on Advances in material and Manufacturing Technology Chitkara University. 2011.

[9] Payal, Himanshu, Maheshwari, Sachin Bharti,PS.: Effect of tool material on surface roughness in electrical discharge machining, Journal of Production Engineering (2016) Vol.19 (1) Novi Sad, ISSN 1821-4932, pp 2730 .

Author: Himanshu Payal, Assistant Professor, Mechanical Engineering, Department ABES, Institute of Technology

E-mail: himanshupayal@,rediffmail.com 